\title{
縄とび運動のエネルギー代謝について
}

小 川 新 吉* 古 田 善 伯* 小 原 繁*
小 原 達 朗* 大 谷 和 寿* 徳 山 薫 平*
古 屋 三 郎**

\section{ON THE ENERGY METABOLISM OF ROPE SKIPPING}

\author{
Shinkichi Ogawa, Yoshinori Furuta, Shigeru Obara, Tatsuro Obara, \\ Kazutoshi Otani, Kunpei Tokuyama and Saburo Furuya
}

In this study, energy consumption of three types of basic rope skipping was measured, together with an investigation of work intensities. The subjects were 5 healthy adult male. The results of this study were as follows :

1) The average relative metabolic rate (RMR) of 1 skip (one skip to one forwardturn of rope), 2 skip (double skip to one forward-turn of rope) and running skip were 13.6, 11.7 and 10.3, respectively, and it was noted that work intensities decrease in order of 1 skip, 2 skp and running skip.

2) On the three types of five minute rope skipping, the oxygen intake for the last one minute of exercise of 1 skip was equivalent to $63.7-78.0 \%$ of maximal oxygen intake, and in cases of 2 skip and running skip were $57.5-76.3 \%$ and $56.8-67.2 \%$, respectively.

3) When skip frequencies of 1 skip were 92,120 and $156 \mathrm{skips} / \mathrm{min}$, respectively, oxygen requirement for $120 \mathrm{skips} / \mathrm{min}$ was the lowest, therefore, it was noted that skip frequency of 120 skips/min was optimal.

(J. Physical Fitness Japan 1974, $23: 89 \sim 95$ )

\section{I.はじめに}

縄とびは古くから子供の遊びとして親しまれて おり，また近年では，体力トレーニングの手段と

して用いられている。

この運動の特徵は, 縄が一本あれば狭い場所で あできること，また，とび方に難易強弱いろいろ の種類があり, 各人の能力に応じたとび方を選択 して実施するてとができることである。したがっ て，今日のように運動する場所が狭ばまりつつあ るなかで，体力の保持増進をねらうとき，縄とび は極めて便利な運動であるといえよう。

ところで, 縄とびに関する科学的研究としては, エネルギー消費量 ${ }^{14) 15)}$, 運動強度 ${ }^{8)}$ およびトレー ニング効果 ${ }^{9}$ 等に関する報告が 2 ・3なされてい
るが，体䏍科学的な面から系統的に解明するには 十分とはいえない。

本研究は, 縄とび運動中であ連続して呼気を採 集できる方法を考案し，エネルギー代謝，さらに 心拍数, 呼吸数等も同時測定し, 縄とび運動の強 度とその特徽を明らかにしようと試みたあのであ る。

\section{II. 研 究 方 法}

\section{(A) 被模者}

被検者は, 年令 $20 \sim 26$ 才の体育研究室に所属 する健康な成人男子 5 名であり，その身体特性は 表-1 に示してある。

(B) 本実群で用いた䋥とびの程類

縄とびは, 縄の回わし方と跳躍のし方をいろい

\footnotetext{
* 東京教育大学スポーツ研究所 Institute of Sport Science, The Faculty of Physical Education, Tokyo University of Education

** 東京教育大学附属小学校 The Elementary School Attached to Tokyo University of Education
} 
Table 1 Characteristics of subjects

\begin{tabular}{|c|c|c|c|c|c|c|c|c|c|}
\hline $\begin{array}{l}\text { Subject } \\
\text { (male) }\end{array}$ & $\begin{array}{l}\text { Age } \\
\text { (yr) }\end{array}$ & $\begin{array}{l}\text { Height } \\
\text { (cm) }\end{array}$ & $\begin{array}{c}\text { Weight } \\
(\mathrm{kg})\end{array}$ & $\begin{array}{c}\dot{\mathrm{VO}_{2}(\mathrm{BM})} \\
(\mathrm{ml} / \mathrm{min}) \\
*\end{array}$ & $\begin{array}{c}\dot{\mathrm{VO}_{2} \max } \\
(1 / \mathrm{min}) \\
* *\end{array}$ & $\begin{array}{c}\dot{\mathrm{VO}}_{2} \mathrm{max} / \mathrm{kg} \\
(\mathrm{ml} / \mathrm{kg} \cdot \min ) \\
* *\end{array}$ & $\begin{array}{c}\dot{\mathrm{V}}_{\mathrm{Emax}} \\
(1 / \min ) \\
* *\end{array}$ & $\begin{array}{l}\text { H.R.max } \\
\text { (beats/ } \\
\underset{* *}{\min } \text { ) }\end{array}$ & $\begin{array}{c}\text { R.R.max } \\
\underset{* *}{\text { (breaths / }} \text { min) }\end{array}$ \\
\hline T.O. & 23 & 170.0 & 59.0 & 209 & 3.737 & 63.3 & 138.9 & 196 & 62 \\
\hline K.T. & 20 & 175.0 & 56.5 & 209 & 3.237 & 57.3 & 136.3 & 186 & 63 \\
\hline K.O. & 26 & 170.0 & 70.0 & 225 & 3.589 & 51.3 & 114.1 & 194 & 65 \\
\hline S.O. & 24 & 170.5 & 59.5 & 211 & 3.426 & 57.6 & 132.3 & 193 & 63 \\
\hline Y.F. & 26 & 175.4 & 69.5 & 229 & 3.606 & 51.9 & 142.9 & 191 & 63 \\
\hline Mean & 23.8 & 172.2 & 62.9 & 216.6 & 3.519 & 56.3 & 132.9 & 192.0 & 63.2 \\
\hline S.D. & 2.2 & 2.5 & 5.7 & 8.6 & 0.172 & 4.4 & 10.0 & 3.4 & 1.1 \\
\hline
\end{tabular}

* Basal $\mathrm{O}_{2}$ consumption

** Maximal values obtained by exhaustive running on treadmill (8.6\% grade, gradual increment of speed)

ろ組み合わせるととにより, 種々のとび方が考え られる。今回は一般化普及している 1 回旋 1 跳躍 前回旋両足とび (以後 1 skip 之略記する), 1 回旋 2 跳躍前回旋両足とび ( 2 skip と略記する), お よびその場かけ足とび (Running skip と略記す る）の基本的な 3 種類のとび方を選らび，それぞ 机しついて 1 分間および 5 分間の連続運動を負荷 した。また，1分間の運動では，1 skip において 跳躍頻度を 92 回/分, 120 回/分, 156 回/分に規定 した場合と, 跳躍頻度を規定せず自由に行なわせ た Voluntary skip（以後 V.S. と略記する）の 4

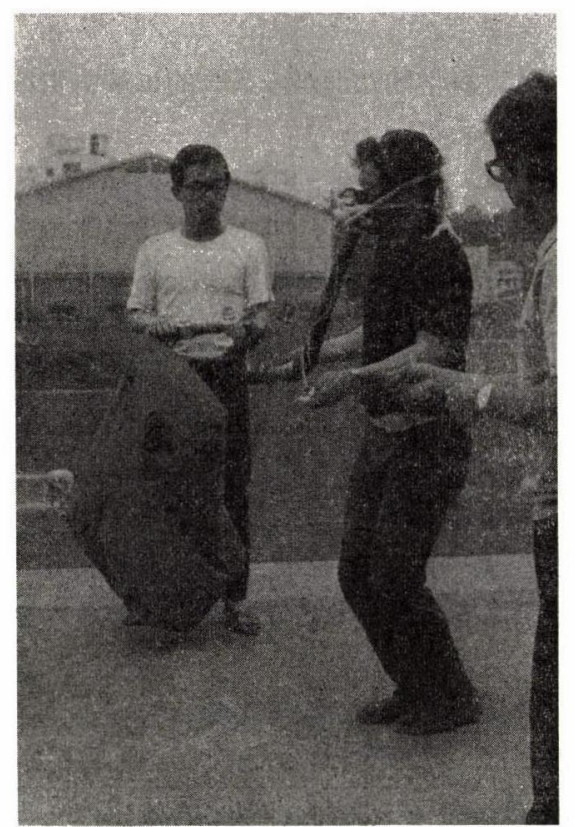

Fig. 1. A photograph of the experimental method
項目を実施した。さらに，2 skip, Running skip においては跳躍頻度を 120 回/分沅規定し，跳躍頻 度はV.S.以外全てメトロノームに合水せて実施し た。

なお，使用した縄は縄とび用に蠟びき加工した 布製の屯のであり，縄とびの名称は古屋 ${ }^{5)}$ の方式 に従った。

(C) 測定方法

縄とび運動中の呼気の採集は, ダグラスバック 法で写真（図-1）に示すように，運動中でも連続 して採気が可能な方法を考案し, 呼気の分析は労 研式ガス分析器を用いた。また, 心拍数はテレメ ーター法, 呼吸数はサーミスタで有線方式により 描記, 算出している。測定は昭和48年 6 月〜 9 月 にかけて実施した。

\section{III. 実 験 結 果}

\section{(A) 3 種類の繩とびのエネルギー代謝}

図-2 は, 1 skip, 2 skip, Running skip の 3 種類のとび方を, 120 回/分の跳躍頻度で 1 分間実 施したときの酸素需要量, 酸素負債, 運動中酸素 摂取量(安静代謝を引いた值), およびエネルギー 代謝率 (RMR) を個人別に示したものである。

酸素需要量は 3 種類のとび方差美がるれ，差 の程度は個人によりかなり大きく異なるが，1 skip, 2 skip, Running skip の順で低くなる傾向 にある。てれを RMR で示すと, 1 skip が 11.1 14. 6(平均 13.6), 2 skip 10.9 12.2(平均 11.7), Running skip 10.5 11.1 (平均 10.3) となり, 運動強度は 1 skip, 2 skip, Running skip の順で 


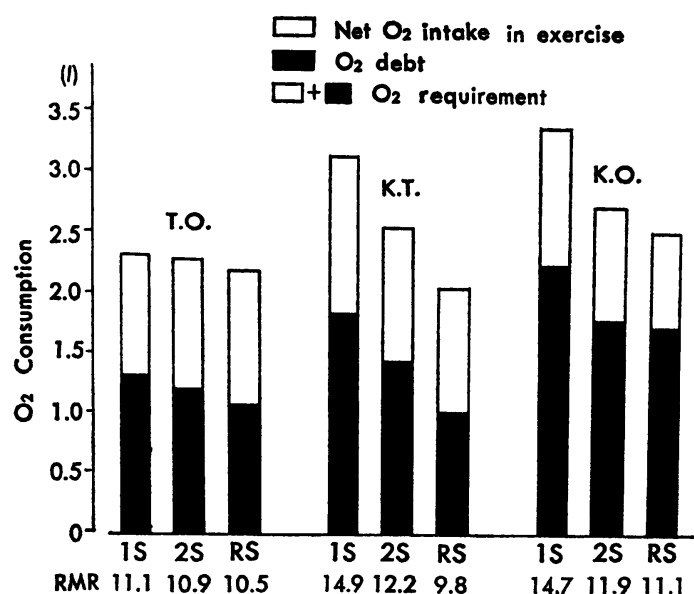

Fig. 2. Oxygen requriement, oxygen debt, net oxygen intake in exercise and RMR (relative metabolic rate) of three types of 1 -minute rope skipping. $1 \mathrm{~S}=1$ skip, $2 \mathrm{~S}=2$ skip, $\mathrm{RS}=\mathrm{Running}$ skip, Skip frequency $=120 \mathrm{skips} / \mathrm{min}$.

低くなる。この関係は，5分間の連続とびにおい ても，ほとんど同じ傾向が得られている。

また，これら 3 種類の縄とびを 5 分間連続して 行なったときの心拍数, 呼吸数, 酸素摄取量, $R Q$
の変化について代表例を図-3 に示してある。

てれらの項目において，3名に共通してみられ た変化について記すと，運動中酸素摄取量は，い ずれの被検者, いずれのとび方の場合においてあ 3 分目あたりから定常状態の成立がみられる。そ こで, 運動中 $4 \sim 5$ 分の酸素摄取量を, 負荷強度 の指標として用いられている最大酸素摄取量に対 する\%1) で示すと，TO では 1 skip が $63.7 \%, 2$ skip 57.5\%, Running skip 54.0\%となり, KT の 場合も同様の順に 78.0\%，76.3\%，56.8\%，KO は69.1\%，68.5\%，67.2\%という值が得られ，と び方の違いあるいは個人間に若干差がみられる。

運動中の心拍数は 1 skip において, 徐々に増加 の傾向がみられ，5分目の心拍数は 155 169 拍 に達しまた 2 skip は 145〜166 拍, Running skip は 146〜160 拍に達しており，乙の両者には 定常傾向もみられている。

$R Q$ は, 運動初期にしばしば安静值より低下し, 運動中止直後には急激な上昇がみられている。

（B）跌蹅頿度が異なる 1 skip のエネルギー消费至 1 skip の縄とび運動について，跳躍頻度を 92 ,

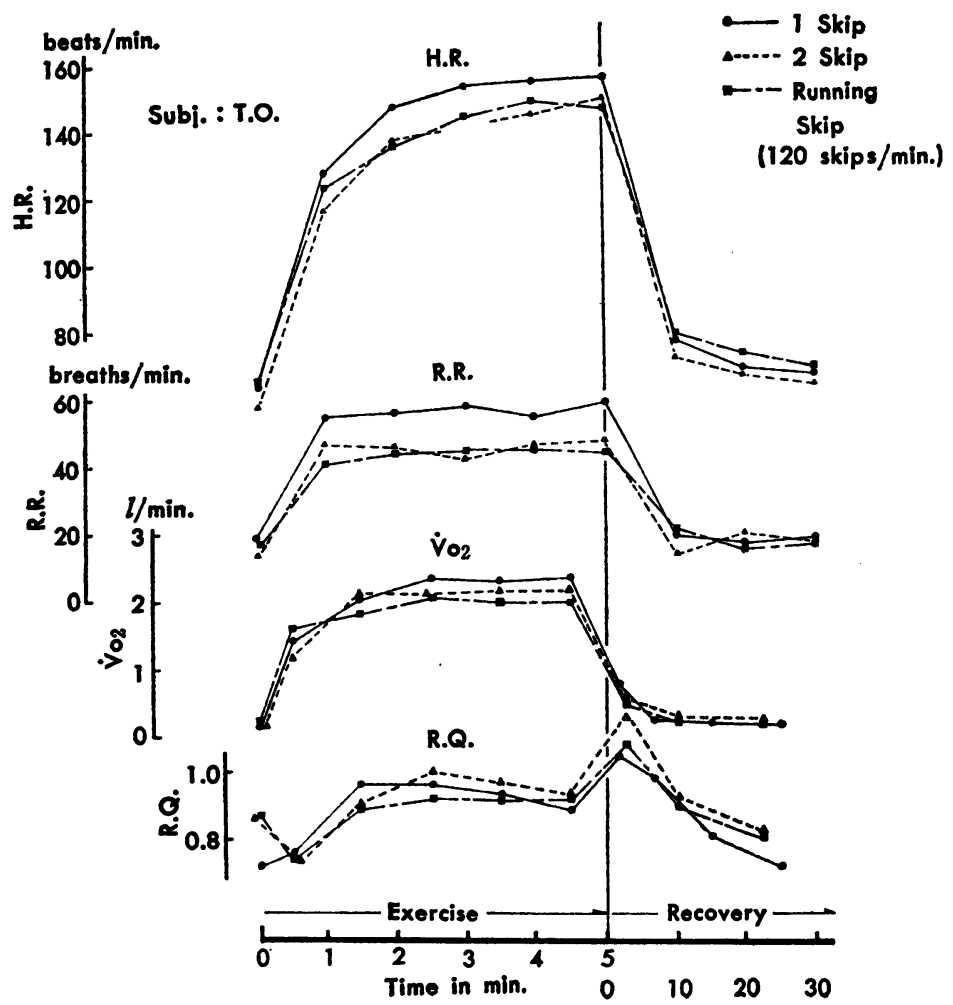

Fig. 3. Changes of heart rate, respiration rate, oxygen intake and respiratory quotient in three types of rope skipping. 
Table 2 Physiological data on different frequencise of 1-minute rope skipping (1 skip).

\begin{tabular}{|c|c|c|c|c|c|c|c|c|c|c|}
\hline \multirow{2}{*}{\multicolumn{2}{|c|}{ Subject }} & \multirow[b]{2}{*}{$\begin{array}{r}\text { Frequency } \\
\text { of skip }\end{array}$} & \multicolumn{4}{|c|}{ During exercise } & \multirow{2}{*}{$\begin{array}{l}\mathrm{O}_{2} \\
\mathrm{Requiremint}_{\text {(1) }}\end{array}$} & \multirow{2}{*}{$\mid \begin{array}{r}\mathrm{O}_{2} \\
\mathrm{Requirement} \\
\quad / 1 \text { skip } \\
(\mathrm{ml})\end{array}$} & \multirow{2}{*}{$\begin{array}{l}\mathrm{O}_{2} \text { debt } \\
\text { (l) }\end{array}$} & \multirow[b]{2}{*}{ R.M.R. } \\
\hline & & & $\begin{array}{l}\text { Net } \\
\mathrm{O}_{2} \text { Intake } \\
(1 / \mathrm{min})\end{array}$ & $\begin{array}{l}\dot{V}_{\text {E }} \text { BTPS } \\
(1 / \mathrm{min})\end{array}$ & $\begin{array}{c}\mathrm{H} . \mathrm{R} . \\
\text { (beats / } \\
\mathrm{min})\end{array}$ & $\mid \begin{array}{c}\mathrm{R} . \mathrm{R} . \\
\left(\begin{array}{l}\text { breaths } / \\
\mathrm{min} \text { ) }\end{array}\right.\end{array}$ & & & & \\
\hline \multirow{4}{*}{\multicolumn{2}{|c|}{ T.O. }} & 92 & 1.399 & 48.8 & 128 & 46 & 3. 550 & 38.6 & 2. 151 & 17.0 \\
\hline & & 120 & 0.999 & 40.9 & 128 & 43 & 2. 320 & 19.3 & 1. 321 & 11.1 \\
\hline & & 156 & 1.249 & 52.4 & 128 & 57 & 3. 032 & 19.4 & 1.783 & 14.5 \\
\hline & & V.S. 124 & 1.170 & 48.2 & 131 & - & 2.805 & 22.6 & 1. 635 & 13. 4 \\
\hline \multirow{4}{*}{\multicolumn{2}{|c|}{ K. T. }} & 92 & 1.387 & 46.4 & 123 & 29 & 4. 097 & 44.5 & 2. 710 & 19.6 \\
\hline & & 120 & 1.265 & 48.9 & 127 & 37 & 3. 111 & 25.9 & 1. 846 & 14.9 \\
\hline & & 156 & 1.474 & 51.4 & 131 & 35 & 3. 759 & 24. 1 & 2. 285 & 18.0 \\
\hline & & V.S. 117 & 0.904 & 49.5 & 122 & 32 & 2. 624 & 22.4 & 1. 720 & 12.6 \\
\hline \multirow{4}{*}{\multicolumn{2}{|c|}{ K. O. }} & 92 & 1.254 & 47.4 & 140 & 37 & 4.509 & 49.0 & 3. 255 & 19.7 \\
\hline & & 120 & 1.143 & 38.9 & - & - & 3. 373 & 28.1 & 2. 230 & 14.7 \\
\hline & & 156 & 1.343 & 57.0 & 144 & 48 & 3. 963 & 25.4 & 2. 620 & 17. 3 \\
\hline & & V.S. 125 & 1.204 & 41. 4 & 135 & 36 & 3.551 & 28.4 & 2. 347 & 15.5 \\
\hline \multirow{3}{*}{\multicolumn{2}{|c|}{ S.O. }} & 92 & 1.152 & 43. 7 & 125 & 41 & 3. 352 & 36.4 & 2.220 & 15.9 \\
\hline & & 120 & 0.985 & 42.9 & 120 & 36 & 3. 162 & 26.4 & 2.177 & 15.0 \\
\hline & & 156 & 1.195 & 61.4 & 135 & 54 & 3. 255 & 20.9 & 2. 060 & 15. 4 \\
\hline \multirow{3}{*}{\multicolumn{2}{|c|}{ Y. F. }} & 92 & 1.594 & 50.0 & 150 & 40 & 6.047 & 65.7 & 4. 453 & 26.4 \\
\hline & & 120 & 1.194 & 34.8 & 151 & 39 & 3. 962 & 33.0 & 2.768 & 17. 3 \\
\hline & & 156 & 1.620 & 51.9 & 150 & - & 4. 742 & 30.4 & 3. 122 & 20.7 \\
\hline \multirow{4}{*}{$\overline{\mathbf{x}}$} & & 92 & 1.357 & 47. 3 & & & 4. 311 & 46.8 & 2.958 & 19.7 \\
\hline & $\mathrm{n}=5$ & 120 & 1.117 & 41. 3 & & & 3. 186 & 26.5 & 2.068 & 14.6 \\
\hline & & 156 & 1.376 & 54.8 & & & 3. 750 & 24.0 & 2. 374 & 17.2 \\
\hline & $\mathrm{n}=3$ & V.S. & 1.092 & 46.4 & & & 2. 993 & 24.5 & 1. 901 & 13.8 \\
\hline
\end{tabular}

V.S. = Voluntary skip

120，156 回/分に規定した運動（5 名）と, 自由 意志でとぶ V.S. の 4 種類の運動（3名）を各被検 者にそれぞれ 1 分間ずつ負荷し，その測定結果を 表-2 に示した。

跳躍頻度を規定したときの酸坫需要量は，いず れの被検者においても120回/分のときが最小で, その平均値は $3.186 \ell(\mathrm{RMR}=14.6)$ となり，92 回/分では $4.311 \ell(\mathrm{RMR}=19.7)$ と最大値を示 し, 156 回/分の場合は $3.750 \ell(\mathrm{RMR}=17.2)$ と 中間値を示している。

そこで, 跳躍頻度の違いによる酸素需要量の差 違について, 酸装負債と運動中酸菜提取量とに分 け，乙れら 3 者の関係を平均值で示すと図 -40 ようになり，酸素需要量は酸素負倩に大きく影嘅 されている。

また，1跳躍当りの酸素需要量を算出してみる
と, 跳躍頻度が少ないほど 1 跳踓当りの酸素需要 量は多くなる傾向にあり，92回/分は120，156回/ 分より1.8〜1.9倍高い值を示している。

次に跳躍頻度を規定しないでとんだV.S.につい てみると, TO は 124回/分, KT 117回/分, KO 125回/分といずれあ120回/分前後の頻度でとんで おり, 酸素需要量等む120回/分前後の值になって いる。

\section{IV. 考察}

本研究は縄とび連動の強度に関して検封を試み たものである。彷来, 運動強度の指想としてエネ ルギー代謝率(RMR)が一般に用いられているが, これは, 運動に対する習熟度 ${ }^{16)}$ や個人の体力レベ ルの差 ${ }^{8) 17)}$ が運動強度 (RMR) に大きく影響して くる。本研究の場合でも, 同一のとび方を同一跳 


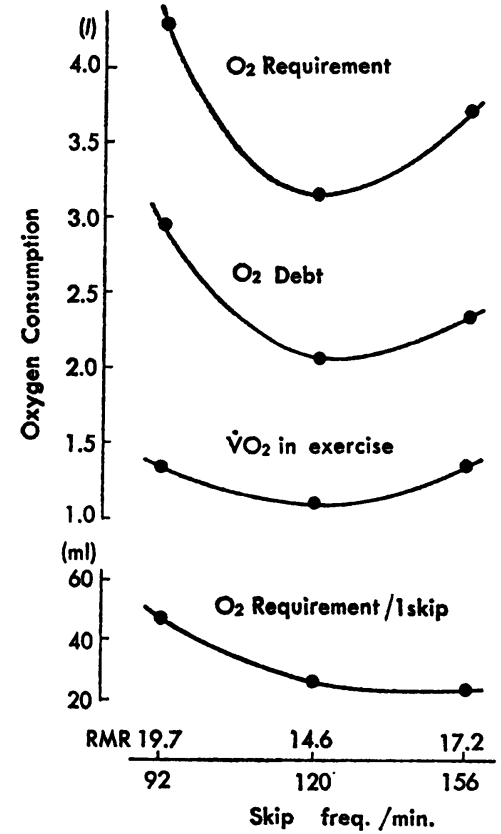

Fig. 4. Each average of oxygen requirement, oxygen debt, net oxygen intake in exercise, oxygen requirement/ 1 skip and RMR (relative metabolic rate) of three different frequencies of 1-minute rope skipping (1 skip).

躍頻度でとんだにもかからず，3 種類のそれぞれ のとび方において RMR の值にかなり大きな個人 差が認められている（図-2 参照)。また, 同一個 人について 3 種類の縄とびの RMR をみると，い ずれの被検者においても 1 skip が最も高く，次い で 2 skip, Running skip の順で低くなることが 認められた。しかし，てれらの值はいずれも相当 高い強度を示しており，他のスポーツと比較し ても，乙れに敵する種目はラグビーの試合24) (11.1), 軟式テニスの前衛2) (12.5), ボートの four work ${ }^{22)}$ (14.7) などがあり，またマラソン25) (15.6)より少し低い程度であることから，本実験 で用いた縄とび運動はかなり激しい身体運動であ り, 長時間の持続運動はきわめて困難であるとい えよう。

特に, 強度の最む高かった 1 skip においては, 自転車エルゴメーターで得られた最大酸素摄取量 よりあ高い值を示したという榎木ら ${ }^{8)}$ の報告もあ り，一般の普通人では，乙の運動を 5 分間連続し てとぶことはまず不可能といってす過言ではな
い。したがって，実際のトレーニングあるいは準 備運動などでこれを用いるときは，運動時間を30 秒〜 1 分間程度にするか，または回数を $60 \sim 120$ 回程度にして，とれを繰り返し行なうようにする のが体験的に適当であると思われる。また，本実 験の結果からみれば体力的に劣っている者には比 較的強度の低い Running skip とか 2 skip 加ら始 めていくのが適当であろう。

ところで，一般に定常状態の成立限界は, RMR が 5 前後であるといわている(10)20)28)。本実験の連 続 5 分間の縄とび運動の結果ではいずれす RMR が約10以上を示し，定常状態の成立はありえない と考えられたが，本実験の被検者はかなりトレー ニングを積んでいるスポーツマンで，体重当りの 最大酸素摄取量 む $51.3 \sim 63.3 \mathrm{ml}$ と一般成人の $49.1 \mathrm{ml}^{\text {b) }}$ より大きい能力の 所有者であったため か, 運動 3 分目でろより酸素摄取量に定常状態の 成立がみられている。しかし，その際の心拍数に は漸增傾向が認められ，真の意味の定常状態 ${ }^{(0)}$ か 否かには問題があり，みかけの定常状態とみる方 が妥当であろう。

そこで次に，縄とび運動中の酸素摂取レベルか ら運動強度を検討してみることにした。

本研究で用いた 1 skip 5 分間の縄とび運動の酸 素摄取量が定常傾向を示したときの值は，トレッ ドミル走で得られた最大酸素摄取量の63.7〜 78.0 \%であった。ての值は黒田ら ${ }^{11}$ の報告によるマラ ソン走行中の $63 \%$ ，あるいは Ferguson") らのア イスホッケー試合中の $66 \%$ に相当しており，また 呼吸循環器系機能を中心とした全身持久性を養成 する運動刺激としては有効》18) と考えられる運動 強度である。

一方, 縄とびの運動強度といっても, とぶ速度, すなわち単位時間当りの跳躍頻度之回旋頻度（以 下跳躍回旋速度之略す）加問題である。そこで, 毎分92回，120回，156回の 3 種の異なる跳躍回旋 速度で， 1 skip の縄とび運動の酸素需要量につい て検討してみた（表-2，図-4 参照)。

跳躍回旋速度が速くなれば，単位時間当りの仕 事量が増し，エネルギーの消費量，換言すれば酸 絭需要量が増大していくことが予測される。とこ ろで，面白いことには，毎分 120 回の跳躍回旋速 度でとんだ場合が, 全例において, 毎分92回でとん 
だ場合より酸素需要量が小さくなるととが認めら れた。このととは，エネルギー消費量の面からみ て，縄とび運動にもとび易い速度，すなわち，歩 行運動 ${ }^{18) 19) 20)}$, 階段昇降運動 ${ }^{12221)}$, 天科棒負荷歩 行 ${ }^{21)}$ 等にみられるような至適速度が存在すること が考えられ，本研究では被検者により若干異なる が, その跳躍回旋速度は毎分 120 回前後であるこ とが実証されたことになる。しかし，今回は毎分 92〜156 回の範囲内で実施しており，ての範囲を はずれた速度においては今後検討する必要があろ う。

\section{V. まをめ}

本研究は, 縄とび運動中においても，連続的に ダグラスバックに呼気の採集が可能な方法を考案 し，基本的な縄とび運動のエネルギー消費量につ いて，とび方と跳躍回旋速度を变えて，実験的な 湘定を実施した。

縄とびの運動強度に関しては，エネルギー代謝 率 (RMR)，および最大酸素摄取量に対する酸素 摄取\%の面から検討を試みた。結果を要約すると 次のようになる。

（1）運動の強度はとび方により異なり，1回旋 1 跳躍前回旋両足とび（1 skip）の RMR は平均 13. 6， 1 回旋 2 跳躍前回旋両足とび（2 skip）は 11.7，その場かけ足とび (Running skip) は10.3 となり, 1 skip, 2 skip, Running skip の順で強 度が低くなることが認められた。

(2) 5 分間の連続縄とび運動中 $4 \sim 5$ 分の酸素 摄取量は, 1 skip の場合, 最大酸素摄取量の 63.7 〜78.0\%, 2 skip は 57.5 76.3\%, Running skip は56.8〜67.2\%にそれぞれ相当していることが認 められ，いわゆる全身持久性のトレーニング手段 として有効な方法と考えられる。

（3）一方，同じ 1 skipでとぶ場合，跳躍回旋速 度が毎分 120 回前後のときエネルギー需要量が最 あ少なく，至適な速度であることが認められた。 （受付 昭和 49 年 6 月 21 日）

\section{文}

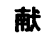

1）朝比奈一男, 浅野勝己，草野勝彦，砂本秀義 （1971）：作業強度の生理的基準について，体力 科学 20(4) : 190-194.
2）浅野辰三(1955) : 軟式庭球試合におけるエネル ギー代謝に関する研究, 第 2 報, 軟式庭球試合 におけるエネルギー需要量—一男子の部, 体育 学研究 2(9) : 550-576.

3）榎木繁男，渡辺和彦，山地啓司，手塚政孝 （1973）:なわとびの 運動効果, 体育の科学 23 (6) : 396-401.

4) Ferguson, R.J., G.G. Marcotte, and R.R. Montpetit(1969) : A maximal oxygen uptake test during ice skating. Med. Sci. Sports, 1 : 207-211.

5）古屋三郎(1972)：なわとび，5版, 不昧堂出版 東京, 33-94.

6) Ikai, M., M. Shindo, and M. Miyamura(1970) : Aerobic work capacity of Japanese people. Res. J. Phys. Ed., 14(3) : 137-142.

7）猪飼道夫, 福永哲夫, 芳賀脩光 (1973)：心拍出 量からみた $70 \% \dot{\mathrm{V}}_{\mathrm{O}_{2}} \max$ 強度による持久性卜 レーニング効果の検討, 体育科学 $1: 67-72$.

8）井上 章(1946)：筋的作業の持久力に関する研 究, 其の 2 , 重筋的作業伦於ける酸素摸取状况 之作業持続能力, 日本生理誌 $10: 82-87$.

9) Jones, D.M., C. Squires, and K.Rodahl(1962) : Effect of rope skipping on physical work capacity. Res. Quart. 33(2) : 66-73.

10）河合清敬(1954)：筋労作の定常状態の成立につ いて，体力科学 4(2)：66-73.

11）黒田善雄, 加賀谷熙彦, 塚越克己, 雨宮輝也, 太田裕造, 成沢三雄 (1969)：陸上長距離走時の 呼吸循環機能の変動, 日本体育協会スポーツ科 学研究報告 NoV., 1-10.

12) Lupton, $H$. (1923) : An analysis of the effects of speed on the mechanical efficiency of human muscular movement. J. Physiol. $57: 337-353$.

13）松井秀治，宮下充正，三浦望慶，小林寛道，長 沢 弘, 水谷四郎, 亀井貞次, 村瀬 豊, 袖山 紘 (1973)：健康成人の Aerobic Work Capacity のトレーニング—Submaximal な運動を継続 するととに対する生体反応一，体育科学 1 ： 125-133.

14）三宅義雄, 川畑愛義, 大山良徳, 八木 保, 三 木直之, 瀬戸 進, 小西博喜, 北橋久子, 高木 敬一(1970)：なわなし「なわとび」動作のエネ ルギー代謝に関する研究, 学校保健研究 12(7) : 324-327. 
15）丹羽 正, 家治川豊, 和久田賢夫(1960)：各種 スポーツの部分的動作に要するエネルギー消費 について, 体力科学 9(2): 57-64.

16）沼尻幸吉(1970)：労働の強さと適正作業量, 8 版, 労㗢科学研究所, 東京, 27

17）沼尻幸吉 (1965)：エネルギー代謝率の恒常性に 関する研究, 労働科学 41(9) : 435-440.

18）奥山美佐雄 (1933)：無負荷歩行時の瓦斯代謝, 労㗢科学研究 $10: 156 \sim 179$.

19）奥山美佐雄 (1933)：負荷歩行時の瓦斯代謝, 労 働科学研究 $10: 305-317$.

20）白井伊三郎, 河合正光, 池田 駿(1955)：昇降 作業のエネルギー需要量とその個人差に就て, 体力科学 4(4) : 134-142.
21）白井伊三郎 (1939)：諸種筋労作に於ける経済速 度に就て, 体育研究 6(4) : 272-293.

22）鈴木義明(1956)：エネルギー代謝の側からみた 力浀の限界について, 体力科学 5(5) : 180-184.

23）鈴木義明(1956)：脈摶数を示標としてみた運動 の質量の恕限界について, 体力科学 6(1) : 1 6.

24）山岡誠一，他 7 名(1952)：ラグビー試合のエネ ルギー代謝，スボーツのエネルギー代謝に関す る研究 (第 4 報), 体育学研究 2(3) : 220-225.

25) Yamaoka, S. (1965) : Studies on energy metabolism in athletic sports. Res. J. Phys. Ed. (9) $3: 28-40$. 